\title{
City Symphonies: The Urban Culture of Expressionist Cinema in 1920s Berlin
}

Taher Abdel-Ghani

vol. 8, 2019, 2, pp. 64-77

DOI: https://doi.org/10.33542/MAD2019-2-04

The Golden Twenties was known to be a period of vibrancy for Berlin which had then became the third largest municipality in the world. Berlin led a sophisticated culture in film, literature, painting, architecture and science. Yet, despite such pros, there emerged a reputation for decadence, for example prostitution and homosexual behaviour. German expressionism had a metaphorical symbolic relationship with the city and the built environment, as Germany began to regain its physical, social and economic structure after the First World War. Its fragmented urban, architectural and spatial character has been depicted as dream-like, chaotic and negatively disordered. On a parallel ideological level, the rapidly changing phenomenon of cities had great influence on artists, poets, writers and filmmakers who found metropolitan street life to be the stage of the magic and chaotic energy then known as city films. This paper highlights the vivid forms of the expressionist city-Berlin's roaring twenties - arising from the alchemy between dark representations and the urban experience. Through a tripartite coalition between Heinrich De Fries's mimesis theory, Michel De Certeau's flâneur and Karl Grune's 1923 expressionist city film Die Straße (The Street), the paper explores the cinematic representation of a once-divided metropolitan city.

Keywords: Urban Culture. Expressionist Cinematic City. Berlin. 1920s.

\section{Introduction}

Modernism presented a break with tradition in Europe beginning in the 1890 s. No longer was space dependent on its corporeal form; space was visually transcribed through its subjective experience. The study of the visual senses proved to be a greatly influential addition to the field of the history of art and architecture in Germany during the time. "Paintings, sculptures, and buildings were evaluated according to psychological and physiological criteria". ${ }^{1}$ Such images were used by Walter Benjamin to describe the value of the camera in discovering the underlying elements of our urban environment through the close examination of familiar objects. ${ }^{2}$ Parallel to this theory was Siegfried Kracauer's contemporary approach to cinematic imaging, which he praised for its technological advancement over photography. ${ }^{3}$ Whilst architecture was struggling to make sense of German aesthetic theory, the new modernist discipline of cinema was already surging ahead, creating spatial depth and movement within a single two-dimensional frame. Cultural life in Weimar Germany has attracted great interest, and several scholarly names have focused on the visual manifestations of modernity, the rise of the avant-garde and the left-wing revolutionary art that appeared during the early 1920s, not just in Germany but other European nations as well.

What has not been explored in detail, which this paper attempts to fill in, is the relation between the cultural history of Weimar Germany and its social, political and economic phases. It is common knowledge that German society underwent dramatic social transformation following the economic crisis between 1929 and 1933, but little is

1 SCHWARZER - SCHMARSOW, The Emergence of Architectural Space, 50.

2 VIDLER, Warped Space, 114.

3 HANSEN, With Skin and Hair. 
known concerning particular aspects of disorder. Cinematic scenery, back then, shifted towards a more subjective, distorted language to depict what the nation was going through; it sought to represent the fragmented and irrational impulses of the modern metropolitan life. This dynamic relationship between film and urban modernity is what is known as the City Symphony. German Expressionism had an ambiguous relationship with the city and the urban environment. Simply put, expressionism rejected naturalistic representation and favoured more expressive, dream-like imaginings of the subconscious, of the repressed condition. This paper adopts Heinrich De Fries's mimesis theory and Michel De Certeau's flâneur in considering Karl Grune's 1923 expressionist film Die Straße (The Street) to reflect the symbolic composition of Weimar's socioeconomic culture.

\section{Modernism...\& Urban Dystopia}

Pre-World War I Berlin was a city craving international recognition - to potentially rival London's imperial stature and Paris's cultural splendour. The "Elektropolis", as Berliners themselves called it (Evans, 2014), was a hub of technological advancement and scientific innovation, especially in the fields of physics and medicine. The nickname had its origins back in the 1896 great industrial exposition of Berlin, held on the $25^{\text {th }}$ anniversary of the German Reich, which showcased a collection of 3,780 businesses and that attracted a total of 7 million visitors. ${ }^{4}$ Prior to the exhibition, Max Ludwig Goldberger, then chairman of the Verein Berliner Kaufleute und Industrieller (Association of Merchants and Industrialists), had written a book called Land der unbegrenzten Moglichkeiten (country of boundless possibilities) the title of which was an equivalent catchphrase to the USA's land of opportunities. It was a call for the world to shift its attention towards what Kaiser Wilhem II had ambitions for the city to become: a Weltstadt (World City). ${ }^{5}$ Upon his arrival in Berlin in the autumn of 1891, Mark Twain, accompanied by his wife and three daughters, called it "the newest city I have ever seen". ${ }^{6}$

Alongside the rapid spread of the modern aesthetics that were reaching daily residential uses, for example the compact bed, the sink unit in the kitchen and children's bunk beds, ${ }^{7}$ German culture was flourishing vividly. The descriptive writings of Friedrich Otto about Berlin's golden twenties ${ }^{8}$ encompass colourful insights into Brecht's and Zuckmayer's theatrical plays, Grosz's and Kollwitz's drawings and Weill's and Schoenberg's music, as well as the diverse productions of the UFA film studio - also mentioning its intention to defy foreign propaganda. ${ }^{9}$ Speculators flocked to the clubs and bars and revolutionized the city's cultural scene. This creative phase was presented to the public in the form of street theatre, cabaret and jazz. By December 1925, a year after the stabilization of the currency, a sense of ultra-modernism surrounded Berlin's Theater De Westens when American cabaret

\footnotetext{
4 GEPPERT, Fleeting Cities.

5 "Berlin 1914: A city of ambition and self-doubt", BBC. Accessed 12 February 2019. https://www.bbc.com/ news/magazine-25635311.

6 AUSTILLAT, Mark Twain in Berlin.

7 HALL, Cities in Civilization.

8 OTTO, Before the Deluge.

9 KREIMEIER, The Ufa Story.
} 
performer Josephine Baker, declared an "erotic goddess", ${ }^{10}$ brought her show from Paris. The following year, German-American cabaret conferencier (master of ceremonies) Erich Lowinsky organized a "Berlin's Got Talent"11 show where young talents were given the opportunity to perform before the public. For the first round, 187 applications were received and all accepted - named the Kabarett der Namenlosen (Cabaret of the Nameless), as if boasting of being "one of the city's typical instances of tastelessness". ${ }^{12}$

In his 1937 talk to an audience of urban planners, Lewis Mumford provided an answer to the socio-existential question "What is a City?", claiming it to be a "theatre of social action [...], a stage-set [which], well-designed, intensifies and underlines the gestures of the actors and the action of the play". ${ }^{13}$ Along the historical timeline, the city has always been a place of excitement, a theatrical arena where citizens display their characters to each other. The title "Modernism \& Urban Dystopia" is borrowed from Gyan Prakash's introduction to his book Noir Urbanisms, ${ }^{14}$ in which he sets out to portray phases of modernity that included the introduction of capitalism and technology alongside the emergence of a routinely consumerist society - a dystopian vision that acted as an initiation for expressionism. Despite Berlin's roaring atmosphere, there existed, on the same sociological level, a reputation for decadence. Prostitution and homosexual behaviour became part of the city's underground economy and culture or, as Mel Gordon puts it, a 'Voluptuous Panic'. ${ }^{15}$ So, on one side of the street, pianist Ernst Engel was performing at the Jockey Bar $^{16}$ - which received a stellar guest-list comprising of Ernest Hemingway, Jean Cocteau and Marlene Dietrich - while on the other side, Artist Ernst Ludwig Kirchner's prostitutes were roaming in their colourful outfits giving provocative glances to the men. ${ }^{17}$

Despite a difference of almost a decade between pianist Ernst and artist Ernst - the latter being the older one - it was definitely a conflicting time for Berliners. Illegal acts took to the streets, to the point that liquor-sellers travelled from one corner to the next selling their wares for one mark per glass. Eroticism became an obsession among the German public as they went out searching for guide books to Berlin's erotic entertainment venues. ${ }^{18}$ In addition to the entertainment side, the public's fascination extended to police reports of lustmord (lust crimes) - and with the increasing numbers of the fascinated, publishing houses decided to release inexpensive lust-homicide novels that involved scientific psychosexual analyses. ${ }^{19}$ Berlin's partial population were

10 "Josephine Baker in Berlin", Cabaret Berlin. Accessed 25 February 2019. http://www.cabaret-berlin. $\mathrm{com} / \mathrm{?} \mathrm{p}=440$.

11 "Berlin's Got Talent", Cabaret Berlin. Accessed 25 February 2019. http://www.cabaret-berlin.com/?p=63.

12 KÄSTNER, The Cabaret of the Nameless, 562.

13 MUMFORD, "What is a City?", 28.

14 PRAKASH, Noir Urbanisms.

15 GORDON, Voluptuous Panic.

16 "Ernst Georg Wilhelm Engel", Comedian Harmonists. Accessed 26 February 2019. http://www.comedianharmonists.net/?page_id=676.

17 "Kirchner \& the Berlin Street", Thread for Thought. Accessed 26 February 2019. http://www. threadforthought.net/kirchner-berlin-street/.

18 GORDON, Voluptuous Panic, 256.

19 GORDON, Voluptuous Panic, 229. 
nothing more than mere clones of Odysseus's shipmates, turned by Circe's curse into pigs - "and when they had drunk she turned them into pigs by a stroke of her wand, and shut them up in her pigsties" 20 - quite an inspiration for George Grosz's 1927 artwork. ${ }^{21}$ Grosz's half-male half-odd-creature characters were dominated mostly by the elite classes of Germany, i.e. businessmen, the clergy and generals. Similarly shocked was Christopher Isherwood upon his arrival among the "neon-lighted shops and bars of Kurfuersten-damm, and [he] entered a modernistic hotel where [he] was surrounded by thick-necked cigar-smoking businessman who might have stepped right out of the cartoon of George Grosz".22
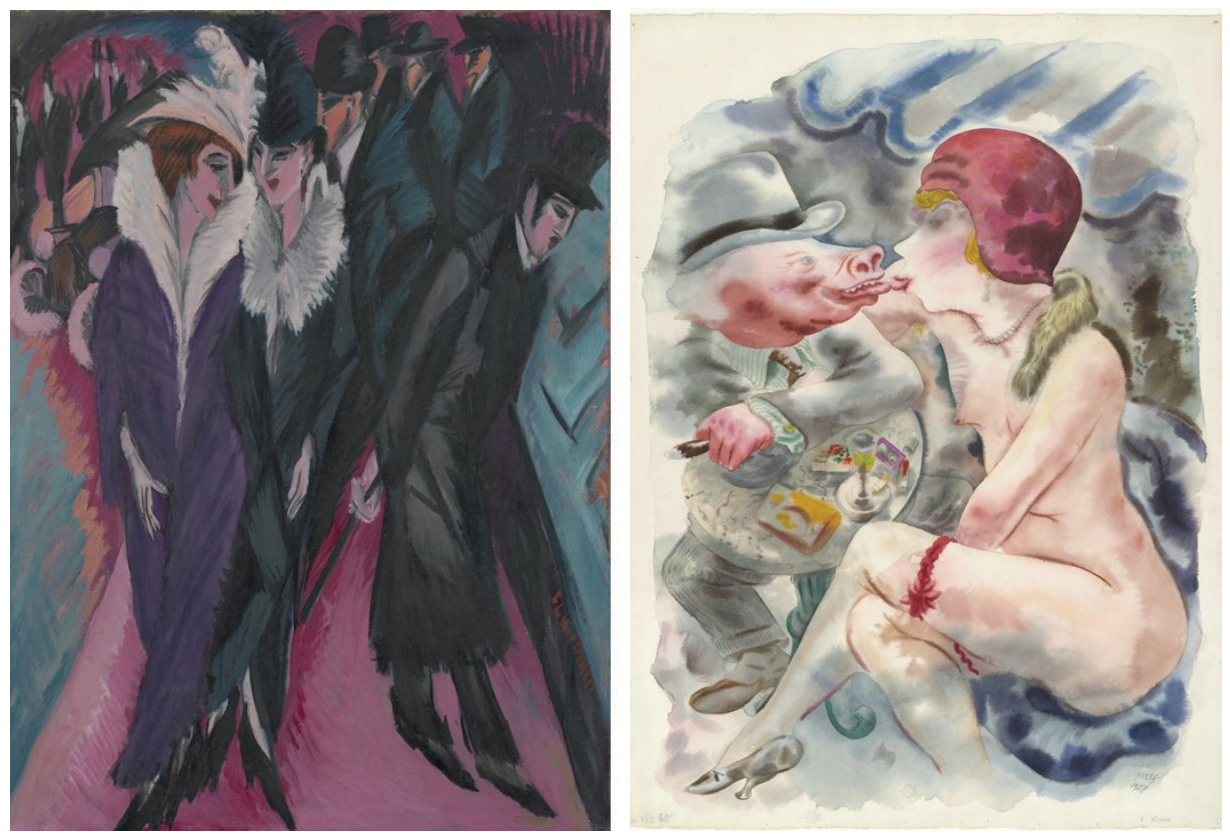

Figure 1: (Left) Ernst Kirchner Street, Berlin (1913) depicting prostitues. (Right) George Grosz Circe (1927) depicting sexually available women and boorishly lewd men during the 1920s

20 HOMER, The Odyssey, 70.

21 "George Grosz: Circe 1927", MoMA, Gallery from German Expressionism: The Graphic Impulse. Accessed 2 March 2019. https://www.moma.org/collection/works/33643.

22 ISHERWOOD, The Berlin Stories, 4. 


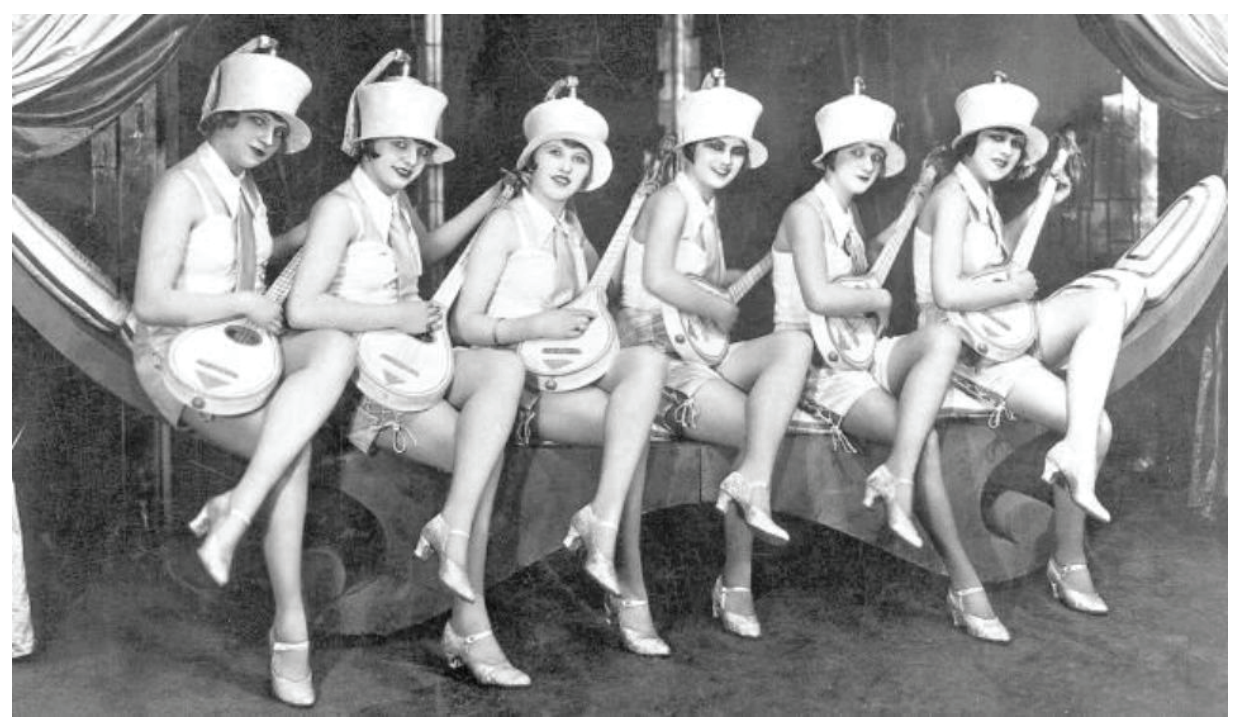

Figure 2: Cabaret dancers in Berlin, 1928. By History ASM (January 31, 2016). Source: http:// historyasm.blogspot.com/2016/01/how-sexual-was-weimar-germany.html

\section{Mimesis of a Fragmented Timeline}

Berlin's cityscape underwent a period of social conflict. Its confrontation with "the new commercial structures and façade renovations in the city centre, the modernist styles in light advertising, shopwindow design, and cinema architecture" 23 eventually left the city with micro narrative fragments that became the subjects of visual exploration. Expressionist writer Hugo Ball, who later became a Dadaist, described Berlin's crisis of modernity in words that draw a clean-cut outline of the silhouette of Cesare, the somnambulist in the 1920 expressionist picture The Cabinet of Dr. Caligari:

"Man lost his heavenly face, became matter, chance, conglomerate, animal, the product of insanity, or abrupt, inadequate and convulsive thoughts. Man lost his special position, which reason had vouchsafed for him". ${ }^{24}$

On a similar level, Michel de Certeau's flâneur-like illustration of walking through the city captures the untangling of complex features and activities. He conceives of a lack of authors or spectators, but rather of a group of moving human figures whose "celestial eye[s]" transform them into gods. ${ }^{25}$ It can be interpreted that De Certeau was attempting to contrast the masses with Joh Fredersen's character in Fritz Lang's Metropolis - for it is not just a single God that looks upon the city, but a whole community of gods that have organized an "all-seeing power". ${ }^{26}$

23 HAKE, Topographies of Class, 134.

24 MURPHY, Theorizing the Avant-Garde, 52.

25 DE CERTEAU, The Practice of Everyday Life, 92.

26 DE CERTEAU, The Practice of Everyday Life, 92. 
The very nature of representation has been under constant debate in the search for a concrete definition. The earliest form of representation was in the theatrical tragedy of the ancient Greek playwright Aeschylus, The Edonians, ${ }^{27}$ where he likens the sound of musical instruments to the voices of raging bulls. György Lukács's perception regarding the novel is that,

"Literature is considered to be representational when it produces a figure of either a particular and recognizable historical, social or psychological reality or, in a more abstract manner, a figure of an ideal, mythical, metaphysical 'reality'". ${ }^{28}$

Berlin's fragmented timeline was depicted, among the majority of the artworks of the period, as the reservoir of urban uncanny, a feeling of discontinuity, instability and disorder within the urban order of reason, transparency and technology. What emerged from the brutally honest form of art back then, that is to say Expressionism, is an alchemy between dark representations and the urban experience. Such alchemy is endorsed in compositions of photography, art, cinema and architecture, where the familiar turns unfamiliar, and the urban order gives way to the unsettling influence of dark mysteries and memories. Dystopic images provide the inflection of human critical meanings, ranging from urban anxiety to utopian desire.

Heinrich De Fries first coined the term mimetic in Raumgestaltung im Film (Spatial Organization in Film) as the act of vision, focusing on the role of perspective and composition to turn a two-dimensional picture plane into a three-dimensional experience. ${ }^{29}$ Objects in space were abstract, and narrative was the tool that gave the film structure and purpose. German cinema presented a certain phenomenon where cinematic images created a series of spaces that would unfold in time, and as Henri Bergson extends the argument, "the image itself is the system of relationships between its elements, which is a set of relationships in time from which the variable present only flows". ${ }^{30}$ Eventually, expressionism produced two ideas about abstract space: the first deals with a space as a three-dimensional dynamic mass, where depth is perceived in a projected film image behind the plane of a cinema screen, whereas the second presents a spatial depth defined by an abstract and fragmented surface space to create the notion of the illusion of space.

\section{The Expressionist Cinematic City: Symphonizing Metonymic Space}

The post-war Berliner was an element in an unstable environment attempting to reconstruct itself in extreme angles. Spatially opposing both the Impressionist appreciation of nature and the majesty of the human form and the well-mannered Baroque, the expressionist city sought to depict the inner harsh reality of modernpaced movement and not to shun the violently unpleasant effect. ${ }^{31}$ Extending the Berliner's gaze from the crude, jagged forms of Die Brücke to the honeycombed maquernas inside the concert hall of Großes Schauspielhaus - designed by Hans

27 HALLIWELL, The Aesthetics of Mimesis, 17.

28 CARROLL, Representation or the End(s) of History, 201.

29 HOLT-DAMANT, Constructs of Space.

30 BERGSON, Matter and Memory, 209.

31 PEDULLÀ, Sull'albero di ciliege. 
Poelzig who applied the same technique to the set of the 1920 film The Golem ${ }^{32}-$ expressionism's ambivalent relationship with the city had begun to blossom.

German Expressionist cinema beginning in the 1920s, and this specific period coinciding with the time of the Weimar Republic, it is also called Weimar Cinema. Two major branches would mark expressionist films at the time, the "romantic" and the "modern". ${ }^{33}$ The romantic is mostly referred to as being highly influenced by the works of the German Romantic painter Casper David Friedrich - specifically The Abbey in the Oakwood painting - with long shots of landscape dissolving within absurd geometrical images of buildings, plays of light and shadow, and magnified doors and windows. Alongside the use of slow-motion and double exposure filmmaking techniques, the romantic expressionist style sought to bring fantasy, non-realism and a hypnotic picture to the foreground, which later inspired other genres to emerge, for example film noir. On the other hand, meanwhile, the modern gave rise to a new genre of film known as the "city film" which "created urbanity as the modern space, and during the 1920s in Europe, this modern city par excellence was Berlin".34

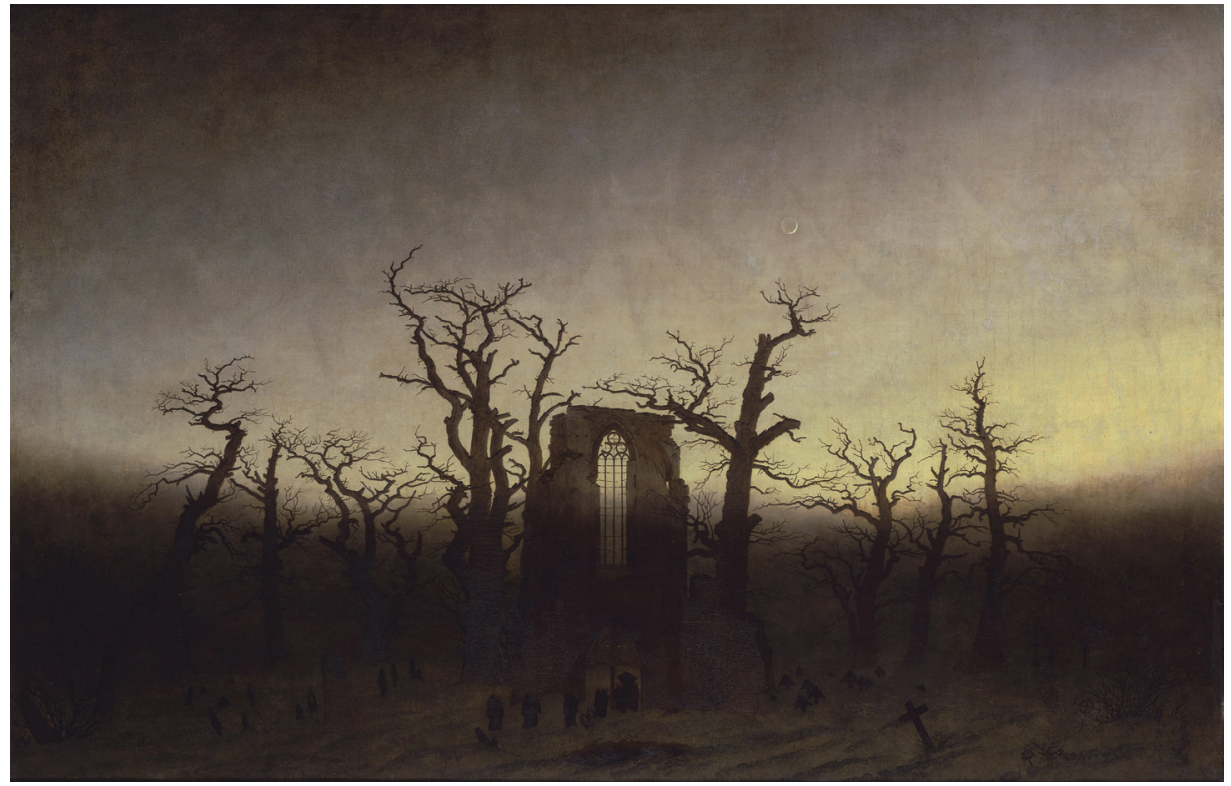

Figure 3: Casper David Friedrich The Abbey in the Oakwood, 1809-10. The painting suggests a deam-like environment of landscape that would be a great inspiration for Expressionist artists

32 "Dreamscape, nightmare, city: the weirded urbanisms of german expressionist film", 3:AM Magazine. Accessed 13 March 2019. https://www.3ammagazine.com/3am/dreamscape-nightmare-city-the-weirdedurbanisms-of-german-expressionist-film/.

33 "German Cinema between 1920 and 1930", Modernism Lab. Accessed 13 March 2019. https://modernism. research.yale.edu/wiki/index.php/German_Cinema_between_1920_and_1930.

34 MENNEL, Cities and Cinema, 21. 
As previously mentioned, expressionist cinema's vivid relationship with the city produced a striking film art genre that influenced several art movements that were to follow. The exaggeration and formal irregularity that appeared on screens across Germany were more of a "revolutionary impulse [...] inscribed into its poetics of representation" 35 - questioning the dominance of the ideological and epistemological foundations of current social discourses. There emerged an affinity between expressionism and the city that captured the gaze of several expressionist filmmakers, who "incorporated elements from the other arts in order to distinguish their own work from conventional films". ${ }^{36}$ Their camera was a visual narrative tool that accepted the current fragmented condition while putting great emphasis on subjective dream-like glimpses of old and new modalities: abstract images of towers, malls, nightclubs and other places the public encounter on a daily basis.

Within this framework, The Cabinet of Dr. Caligari reveals a quite distorted human figure who haunts the city - a film about psychosis, sleep and murder. It seeks out to blur the thin line between fiction and reality, with images such as contorted doors, black and white spiral staircases, sharp edged crenellations and tormented sets. The slanted buildings suggest a horror-like nightmare haunting the city during its sleep time, an environment that was created to evoke an unreal space. ${ }^{37}$ The story was actually a revolutionary resistance against the omnipotence of a state authority that had declared war during World War $1 .{ }^{38}$ Caligari was the political figure that idolized the power to violate all human rights policies and values. This film recreates reality in a fun house mirror to give the feeling of a wavy-like dream. Familiar forms are replaced with troubling forms. Instead of filming "real" houses, corridors or stairways, it was necessary to produce and expand what Lotte Eisner called "Landschaft mit Seele" (landscape with soul). ${ }^{39}$ Thus, filmmakers were forced to create films about the soul's interior life within the pure and abstracted interior space of the studio. Furthermore, the film carries a distinct relation to Postwar Germany through the character Dr Caligari and his ability to travel and kill indiscriminately, which is a symbol of the nation's state of disarray. The horror content of the film's story represents a country in the midst of turmoil at its most basic level, a metaphorical visual aspect of Germany's struggle to survive. ${ }^{40}$

35 MURPHY, Theorizing the Avant-Garde, 51.

36 HAKE, Expressionism and Cinema, 331.

37 "Dreamscape, nightmare, city: the weirded urbanisms of german expressionist film", 3:AM Magazine. Accessed 13 March 2019. https://www.3ammagazine.com/3am/dreamscape-nightmare-city-the-weirdedurbanisms-of-german-expressionist-film/.

38 "The Cabinet of Dr. Caligari", Modernism Lab. Accessed 15 March 2019. https://modernism.research.yale. edu/wiki/index.php/The_Cabinet_of_Dr._Caligari.

39 EISNER, The Haunted Screen, 151.

40 "The Cabinet of Dr. Caligari: Dark Relationship with Postwar Germany", The Artifice. Accessed 15 March 2019. https://the-artifice.com/the-cabinet-of-dr-caligari-dark-relationship-with-postwar-germany/. 


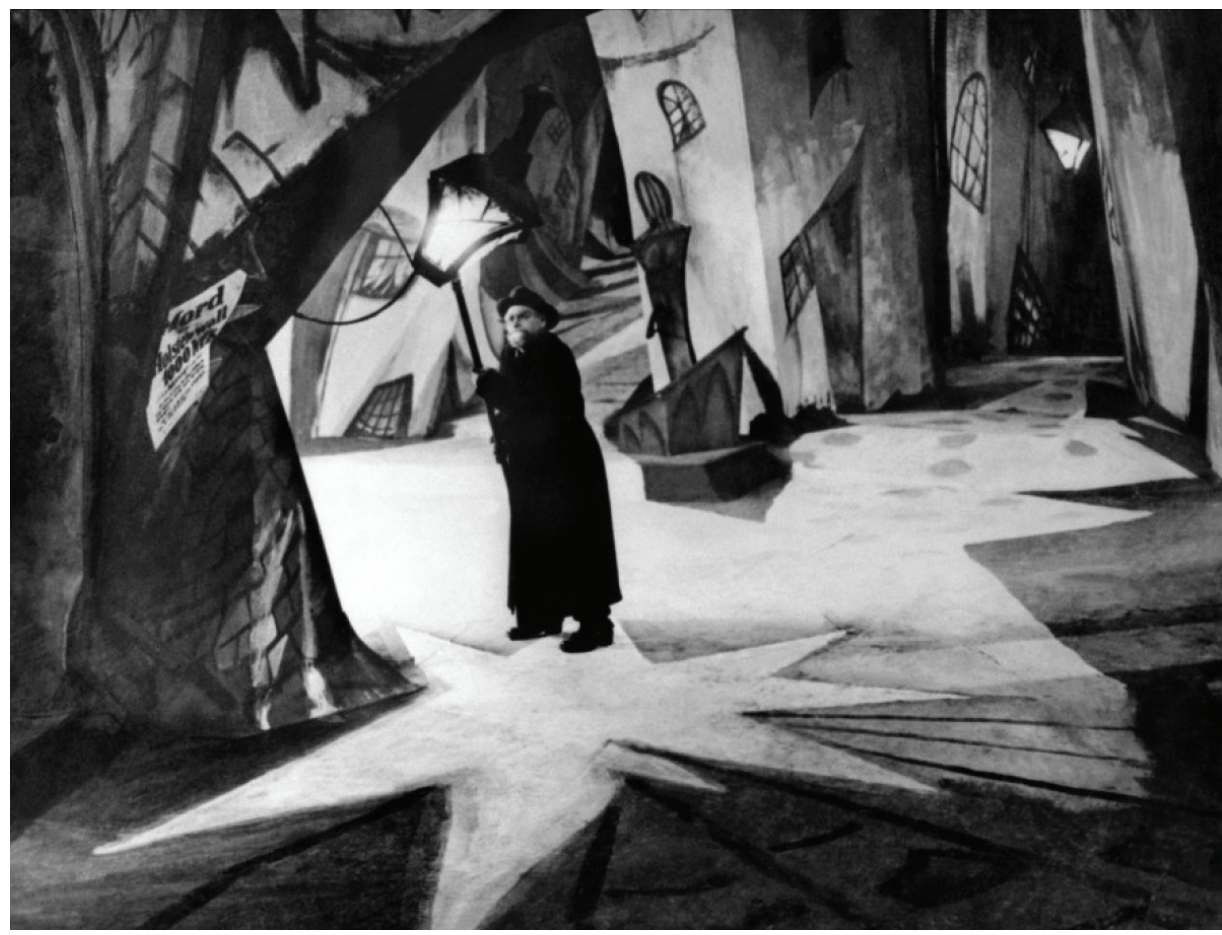

Figure 4: The notion of 'landscape with soul' as represented in an abstract sharp-edged mirror, The Cabinet of Dr. Caligari, 1920. Source: http://screenprism.com/insights/article/why-is-the-cabinet-of-dr.-caligari-considered-the-definitive-german-express

\section{A Closer Look at Karl Grune's Die Straße (1923)}

Die Straße (The Street) is considered among the early street films that address the lure of the metropolitan universe crowded with the multiple narratives and complexities of the modern era. It follows a bourgeois middle-aged man who is lured away from his empty dull life into the pleasures of the big city night-life, leading to unfortunate consequences. Despite the use of expressionist lighting techniques, there is no use of distorted sets. Being focused more on the inner feelings of the main protagonist, the film is mainly synthesized somewhere between expressionism and impressionism. It takes quite a lighter approach to convey the nightmarish atmosphere of the city as opposed to Caligari.

Premiered in Berlin on 29 November 1923, the film portrays the main protagonist as the curious flâneur wandering from street to street, distressed and alone amidst the crowds and speeding automobiles. His emotions of longing for the city are expressed earlier in the film when, lying down at home, he glances at the ceiling and on it is projected the shadow, from the street lights, of a couple creeping in - a sight that doesn't seem to be visible to his wife who is routinely preparing soup. It can be argued that the main character has been promised sheer joy, excitement and adventurous 
lifestyles, all brought to the world by the twentieth century ${ }^{41}-$ further expressed in the film by the harlot who seduces the man to follow her all night. Drawing a few visual inspirations from the 1920 expressionist picture Von Morgen bis Mitternachts (From Morn to Midnight), the film induces a nihilistic tone reflecting Weimar's bleak societal issues. In one scene, the man follows a young woman in the street whose face is immediately replaced by a skull mask upon him seeing her. Very similarly to in Von Morgen, the young woman in both scenes is a nihilist symbol of modern society as a composite of dead individuals running around aimlessly.
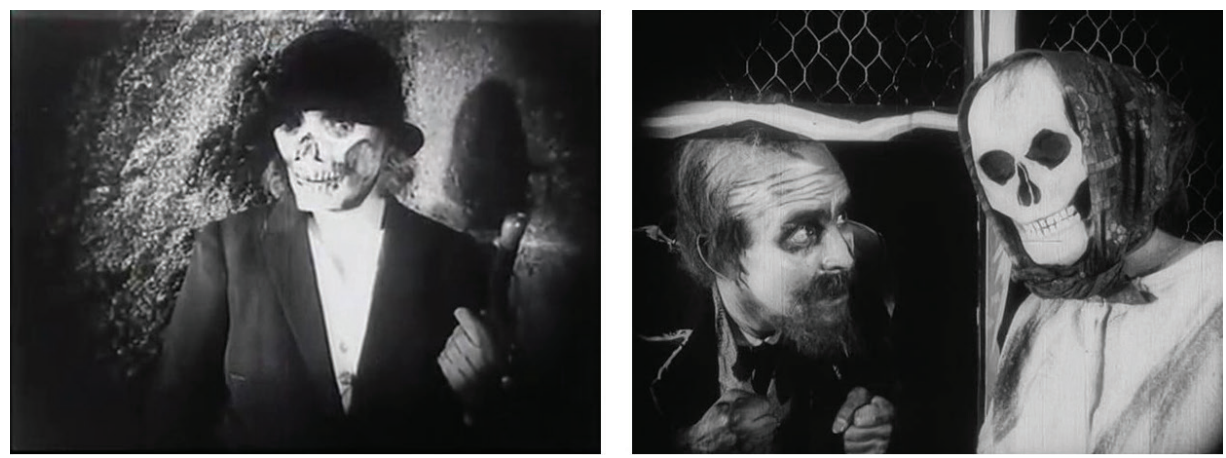

Figure 5: (Left) Woman's face transformed into a skull, The Street (1923). (Right) The same effect applied earlier, From Morn to Midnight (1920). Both women express the condition of death and nothingness.

Our main character here is considered what Baudelaire refers to as "a kaleidoscope gifted with consciousness, responding to each one of its movements and reproducing the multiplicity of life [...] he is an 'I' with an insatiable appetite for the 'non-I'".42 Unlike Walter Ruttman's Berlin: Symphony of a Metropolis (1927) - where the camera is the flâneur figure - Karl Grune created a contemporary city stroller who is a symbolic reflection of ourselves sauntering around observing everything encircling our vicinity. As much as the view of the city visible in the background scenery of the public park where the man won't get close to the harlot as people pass by - is quite vivid and gives a positive impression of a city's social silhouette, eventually it is all an illusion. Guilt creeps through the protagonist as spectacles light up in omniscient neon, gazing directly at him, as though he is being watched. The whole city watches everybody - the blurry lines between the public and the private have become a definitive feature of modernism. Additionally, the protagonist is compelled to follow a luminous neon sign on the ground pointing towards the cabaret entrance - a sign that would later be tackled by Jean-Luc Godard in his 1965 picture Alphaville. ${ }^{43}$ Leisure becomes overwhelming, the wonderment of the city lights are starkly juxtaposed with a feeling of vertigo when the cabaret scenery starts spinning around, and the image of the protagonist's wife fades away from within the frame of the ring.

41 HARVEY, The Condition of Postmodernity.

42 BAUDELAIRE, The Painter of Modern Life, 15.

43

ABDEL-GHANI, The Conspicuous Past-Present Similitude. 


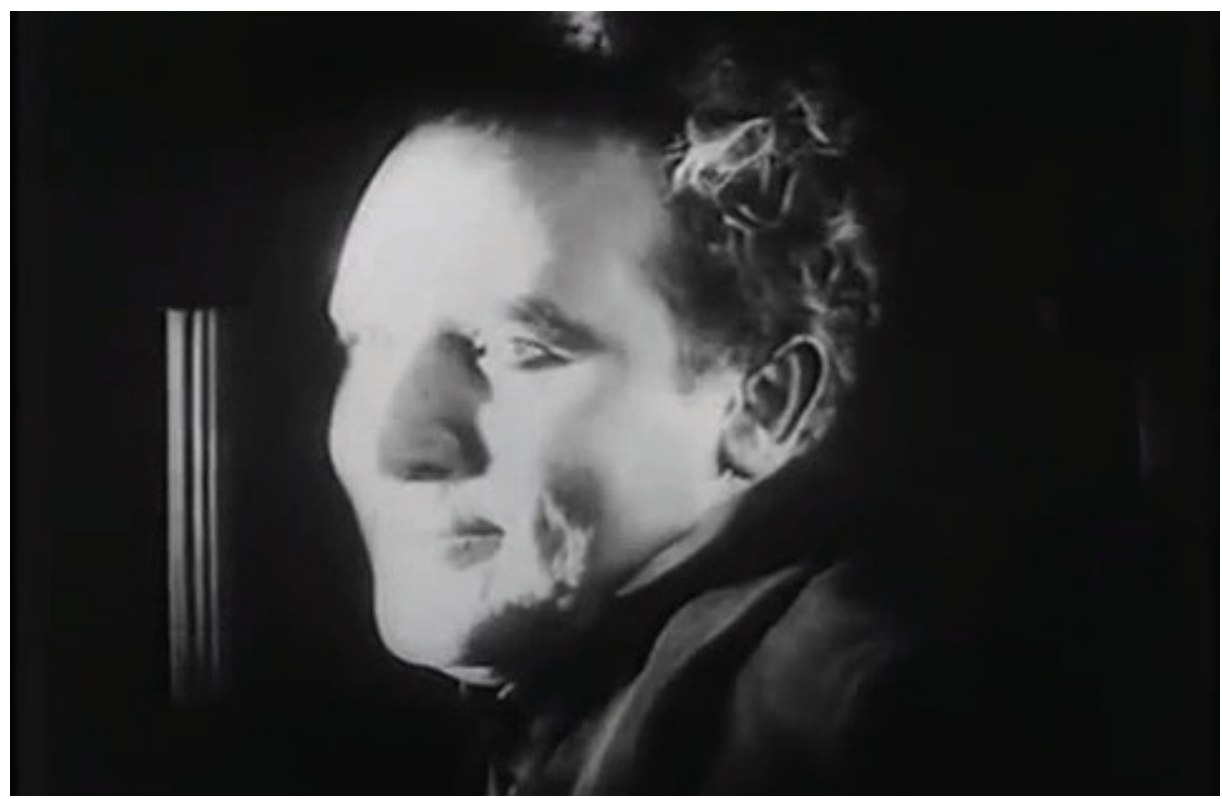

Figure 6: The main protagonist gazes out of his window onto the "pleasures" of the street as a means to escape his routine life, The Street (1923)

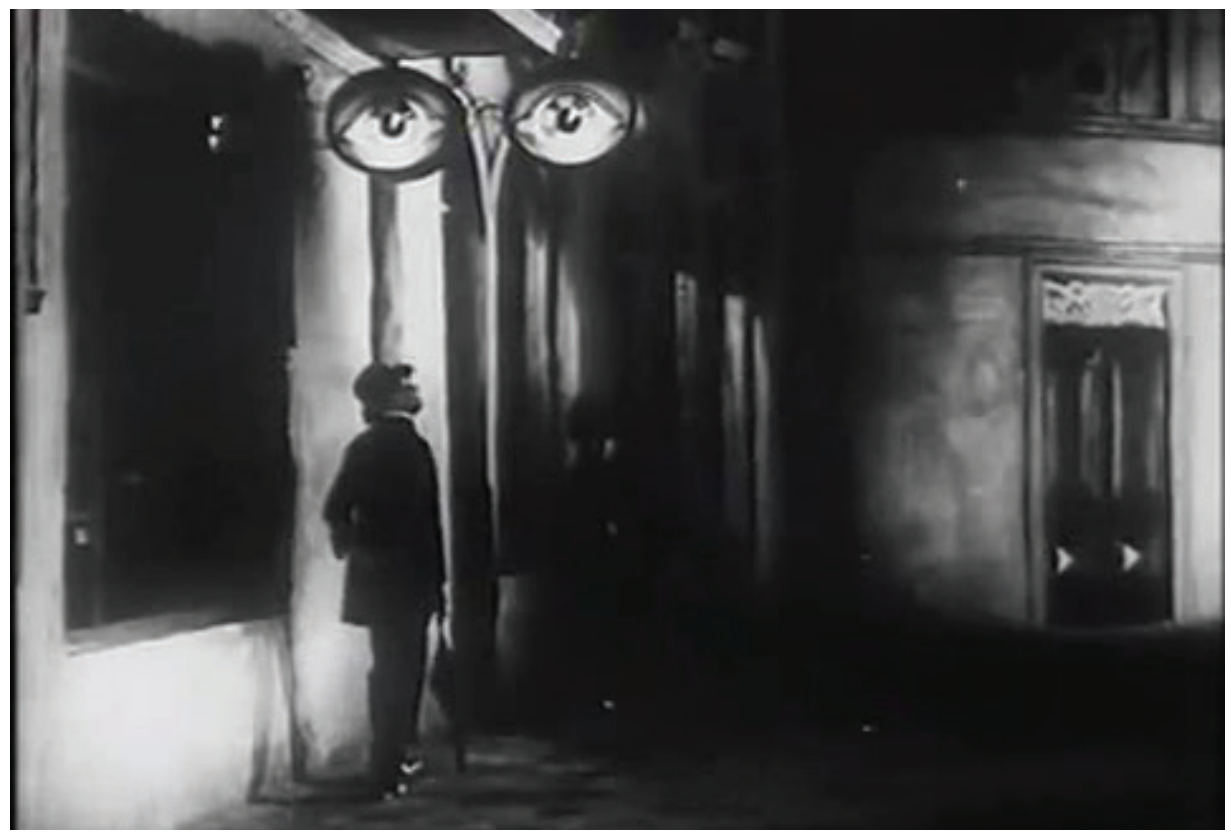

Figure 7: Street lights light up as "human eyes" watching everybody. The main character creeps away in fear, The Street (1923) 
On a parallel note, an old blind man lives with his grandson whose father leaves them for the sake of pursuing luxurious profit - a major core generator of fragmentation and discontinuity generated by the metropolitan city, casting retrospection upon the major shifts heralded by the coming of the twentieth century. ${ }^{44}$ This corresponds to Georg Simmel's concern that, with postmodernity, an individual's mind is stimulated to such an extent that it ceases to show any reaction to the disruptions and complexities of the modern city. ${ }^{45}$ This stimulation is further visualized when the boy gets lost in the midst of the bustling traffic and the blind man struggles continuously not just to find him but also to find his way around. That scene alone, sliced from the movie as a whole, can be argued to be the underlying scene for Virginia Woolf's 1926 statement, "the past could be unrolled, distances annihilated [...] in the chaos of the streets". ${ }^{46}$

The continuous intercuts between progression, both in the streets and inside the cabaret, reveal the state of flux that dominated the city at the time. Anthony Coulson's interpretation degrades the street from any active participation in the main narrative; rather it is more of a metaphorical feature of blindness, vulnerability and distraction. ${ }^{47}$ The frenzy-like activity of the street is a direct reflection of the nervous exotic energy of city dwellers isolated from one another by their own attempts to find refuge solitarily. On a similar note, the behaviour of the citizens inside the cabaret, despite having an expressionistic stylized manner, mirrors the exterior urban scenery. As clarified by Coulson, these are human figures who "move ghostlike in and out of the shadows, untouching, unseeing and unknowing". ${ }^{48}$ A spatial manifestation of Fitzgerald's The Great Gatsby, the city's social inequality denies social mobility - as is further emphasized through intercuts. The middle-aged bourgeois and the old blind man are separated by Berlin's disaffirmation of clear and concrete directions. To facilitate complications, the character of the harlot bridges the two storylines by the end of the film, signifying the fading away of the boundaries between cabaret and legitimate theatre. The harlot, among other erotic performers such as Anita Berber, contributed to the formation of the city's notorious underground culture that encompassed druguse and prostitution.

Other expressionist city symphonies that followed would be F.W. Murnau's The Last Laugh (1924), G.W. Pabst's Joyless Street (1925), Walter Ruttman's Berlin: Symphony of a Great City (1927) and Fritz Lang's Metropolis (1927). All of these, produced in the same decade, emphasize the dangers and pleasures of modern urban life.

\section{Conclusion}

The city has always been particularly important in understanding how social change manifests itself. Berlin's 'roaring twenties' period was of many social contrasts. While a large portion of the population struggled with high unemployment and deprivations in the aftermath of World War I, the upper class society gradually recreated prosperity and transformed Berlin into a cosmopolitan city. Films have become a subject of attention within urban studies to be addressed as cultural visions of what cities represent, as it is considered to be a peculiar spatial form of culture. Expressionist films

\footnotetext{
44 SIMMEL, The Metropolis and the Mental Life, 175.

45 SIMMEL, The Metropolis and the Mental Life, 176.

46 WOOLF, The Cinema, 176.

47 COULSON, Entrapment and Escape, 193.

48 COULSON, Entrapment and Escape, 194.
} 
have reflected Berlin's social differences in class, gender, age, race, and ethnicity, and portrayed such urban patterns code neighbours as rich or poor, or landscapes as urban or rural. Since the turn of the $20^{\text {th }}$ Century, dystopic images have created prominent figures in literature and cinema as sociological representations of the modern city. What characterizes expressionism is not just the bleak mood but also the mode of interpretation - a uniquely crafted critical reading of specific historical conditions to diagnose crisis and catastrophe.

\section{BIBLIOGRAPHY}

ABDEL-GHANI, Taher. The Conspicuous Past-Present Similitude in Godard's Alphaville. In:

International Social Sciences and Interdisciplinary Studies, 2018, no. 2, pp. 45-61.

AUSTILLAT, Andreas. Mark Twain in Berlin: Newly Discovered Stories \& an Account of Twain's Berlin Adventures. New York: Berlinlica Publishing LLC, 2015.

BAUDELAIRE, Charles. The Painter of Modern Life \& Other Essays. Edited by Jonathan Mayne. London: Phaidon, 1999.

BERGSON, Henri. Matter and Memory. Massachusetts: Courier Cooperation, 2004.

CARROLL, David. Representation or the End(s) of History: Dialectics and Fiction. In: Yale French Studies, 1980, no. 59, pp. 201-229.

COULSON, Anthony. Entrapment and Escape: Readings of the City in Karl Grune's The Street and G.W. Pabst's The Joyless Street. In: SCHEUNEMANN, Dietrich (ed.).

Expressionist Film: New Perspectives. Rochester: Camden House, 2003, pp. 187-211.

DE CERTEAU, Michel. The Practice of Everyday Life. Berkeley; Los Angeles; London:

University of California Press, Ltd., 1984.

EISNER, Lotte. The Haunted Screen: Expressionism in the German Cinema and the Influence of Max Reinhardt. Berkeley; Los Angeles: University of California Press, 2008.

GEPPERT, Alexander. Fleeting Cities: Imperial Expositions in Fin-de-Siècle Europe. London: Palgrave Macmillan UK, 2010.

GORDON, Mel. Voluptuous Panic: The Erotic World of Weimar Berlin. Los Angeles: Feral House, 2006.

HAKE, Sabine. Expressionism and Cinema: Reflections on a Phantasmagoria of Film History. In: DONAHUE, Neil H. (ed.). A Companion to the Literature of German Expressionism. Rochester: Camden House, 2005, pp. 321-343.

HAKE, Sabine. Topographies of Class: Modern Architecture and Mass Society in Weimar Berlin. Michigan: University of Michigan Press, 2008.

HALL, Peter. Cities in Civilization. London: Weidenfeld \& Nocolson, 1998.

HALLIWELL, Stephen. The Aesthetics of Mimesis: Ancient Texts and Modern Problems. Princeton: Princeton University Press, 2002.

HANSEN, Miriam. "With Skin and Hair": Kracauer's Theory of Film, Marseille 1940. In: Critical Inquiry, 1993, vol. 19, no. 3, pp. 437-469.

HARVEY, David. The Condition of Postmodernity: An Enquiry into the Origins of Cultural Change. Oxford: Blackwell Publishers, 1990.

HOLT-DAMANT, Kathi. Constructs of Space: German Expressionism, Mies van der Rohe and Yasujiro Ozu. In: GUSHEH, Mayam - STEAD, Naomi (eds.). 20th Annual Conference of the Society of Architectural Historians Australia and New Zealand. Sydney: Society of Architectural Historians, Australia and New Zealand, 2003, pp. 152-157.

HOMER. The Odyssey. Translated by Samuel Butler. California: CreateSpace, 2011.

ISHERWOOD, Christopher. The Berlin Stories. New York: New Directions Publishing Corp., 1945.

KÄSTNER, Erich. The Cabaret of the Nameless (1929). In: KAES, Anton - JAY, Martin DIMENDBERG, Edward (eds.). The Weimar Republic Sourcebook. Berkeley; Los Angeles; London: University of California Press, 1995, pp. 562-563.

KREIMEIER, Klaus. The Ufa Story: A History of Germany's Greatest Film Company, 19181945. Berkeley; Los Angeles; London: University of California Press, 1999. 
MENNEL, Barbara. Cities and Cinema. London; New York: Routledge, 2008.

MUMFORD, Lewis. "What is a City?" taken from Architecture Record 1937. In: MILES, Malcolm - HALL, Tim - BORDEN, Iain (eds.). The City Reader. London: Routledge, 2000, pp. 28-33.

MURPHY, Richard. Theorizing the Avant-Garde: Modernism, Expressionism, and the Problem of Postmodernity. Cambridge: University of Cambridge Press, 2004.

OTTO, Friedrich. Before the deluge: A Portrait of Berlin in the 1920s. New York: HarperCollins, 1972.

PEDULLÀ, Gabriele. Sull'albero di ciliege. Conversando di letteratura e cinema con Alberto Arbasino. In: Contemporanea, 2003, no. 1, pp. 147-159.

PRAKASH. Gyan (ed.). Noir Urbanisms: Dystopic Images of the Modern City. Princeton: Princeton University Press, 2000.

SCHWARZER, Mitchell - SCHMARSOW, August. The Emergence of Architecture Space: August Schmarsow's Theory of "Raumgestaltung”. In: Assemblage, 1991, no. 15, pp. 48-61. SIMMEL, Georg. The Metropolis and the Mental Life. Chicago: University of Chicago Press, 1903.

VIDLER, Anthony. Warped Space: Art, Architecture, and Anxiety in Modern Culture. Cambridge, Massachusetts: The MIT Press, 2000.

WOOLF, Virginia. The Cinema. In: Selected Essays. Edited by David Bradshaw. Oxford: OUP, 2009, pp. 172-176.

"Berlin 1914: A city of ambition and self-doubt", BBC. Accessed February 12, 2019. https:// www.bbc.com/news/magazine-25635311.

"Berlin's Got Talent”, Cabaret Berlin. Accessed February 25, 2019. http://www.cabaret-berlin. $\mathrm{com} / \mathrm{p}=63$.

"Dreamscape, nightmare, city: the weirded urbanisms of german expressionist film", 3:AM Magazine. Accessed March 13, 2019. https:/www.3ammagazine.com/3am/dreamscapenightmare-city-the-weirded-urbanisms-of-german-expressionist-film/.

"Ernst Georg Wilhelm Engel”, Comedian Harmonists. Accessed February 26, 2019. http:// www.comedian-harmonists.net/?page_id $=676$.

“George Grosz: Circe 1927”, MoMA, Gallery from German Expressionism: The Graphic Impulse. Accessed March 2, 2019. https://www.moma.org/collection/works/33643.

“German Cinema between 1920 and 1930", Modernism Lab. Accessed March 13, 2019. https:// modernism.research.yale.edu/wiki/index.php/German_Cinema_between_1920_and_1930.

“Josephine Baker in Berlin”, Cabaret Berlin. Accessed February 25, 2019. http://www.cabaretberlin.com/?p=440.

"Kirchner \& the Berlin Street", Thread for Thought. Accessed February 26, 2019. http://www. threadforthought.net/kirchner-berlin-street/.

“The Cabinet of Dr. Caligari”, Modernism Lab. Accessed March 15, 2019. https://modernism. research.yale.edu/wiki/index.php/The_Cabinet_of_Dr._Caligari.

"The Cabinet of Dr. Caligari: Dark Relationship with Postwar Germany", The Artifice. Accessed March 15, 2019. https://the-artifice.com/the-cabinet-of-dr-caligari-dark-relationshipwith-postwar-germany/. 